\title{
Agricultural Marketing in Belgium and the Netherlands
}

\author{
Matthew Meulenberg \\ Jacques Viaene
}

\begin{abstract}
SUMMARY. Agriculture in Belgium and the Netherlands has a strong export tradition and has been market oriented for a long time. In this article agricultural marketing in Belgium and the Netherlands is analyzed on the basis of the concepts structure, conduct and performance. In our review of market structure attention is paid to the structure of agriculture, the food consumer, food retailing, government policies, competition and marketing channels. Afterwards market conduct with respect to product, price, promotion and distribution is discussed. Finally some qualitative observations are made on marketing performance.

It is concluded that agricultural marketing policies in Belgium and the Netherlands are increasingly focusing on value added to the agricultural product. As a result vertical marketing systems/food chain and marketing management become familiar concepts to agricultural marketing.
\end{abstract}

\section{INTRODUCTION}

Dutch and Belgian agriculture by tradition is market oriented. In particular Dutch agriculture is export oriented. The attractive geo-

Matthew Meulenberg is affiliated with the Agricultural University Wageningen. Jacques Viaene is affiliated with the State University of Gent.

[Haworth co-indexing entry note]: "Agricultural Marketing in Belgium and the Netherlands." Meulenberg, Matthew and Jacques Viaene. Co-published simultaneously in the Journal of International Food \& Agribusiness Marketing (The Haworth Press, Inc.) Vol. S, No. 3/4, 1993, pp. 141-161; and: Food and Agribusiness Marketing in Europe (ed: Matthew Meulenberg), The Haworth Press, Inc., 1993, pp. 141-161. Multiple copies of this article/chapter may be purchased from The Haworth Document Delivery Center [1-800-3-HAWORTH; 9:00 am. - 5:00 p.m. (EST)].

(c) 1993 by The Haworth Press, Inc. All rights reserved. 
graphic situation of both countries between urbanized regions of Germany, Great Britain and France, a mercantile tradition, and an open market policy of governments have stimulated market orientation.

In the first half of this century agricultural marketing in both countries primarily was concerned with the effectiveness and efficiency of marketing functions and marketing institutions.

Problems and policies of agricultural marketing have changed during the past thirty years, amongst others because of changing consumers, of changing market structure, and-during the past fifteen years-because of societal concern about the physical environment. As a result marketing management has become relevant in agriculture too.

Not only changes in the socio-economical environment of agriculture and agribusiness, but also endogenous changes in agriculture and agribusiness themselves, such as new production technologies and changing agribusiness structures have increased the relevance of marketing in agriculture.

Agricultural marketing in Belgium and the Netherlands will be discussed in this article, in particular present developments. We will base our analysis on the concepts Structure, Conduct, Performance (Bain, 1956; 1959). The article is organized as follows. Firstly market structure is analyzed by discussing successively consumers, competitors, food retail and government policies. The section on market structure ends up with an analysis of marketing channels and marketing institutions. Subsequently marketing conduct is analyzed with respect to marketing instruments and marketing policies. Finally, the performance of agricultural marketing is evaluated briefly.

\section{MARKET STRUCTURE OF BELGIAN AND DUTCH AGRICULTURE}

\section{Some Facts About Belgian and Dutch Agriculture}

Agriculture is no longer a dominating sector of the Belgian and Dutch economy: in 1987 agricultural income as a percentage of 
National Income amounted in Belgium and the Netherlands to respectively $1.9 \%$ and $3.9 \%$. Of total labor force $2.5 \%$ and $5.4 \%$ were employed in Belgian respectively Dutch agriculture (LEI-DLO, 1989 ) and an additional $3.2 \%$ respectively $3.4 \%$ of total labor force were employed in food industry of both countries (LEI-DLO, 1989; NIS, 1991).

Agriculture and agribusiness contribute substantially to national exports: of total Dutch exports in 1990 about $24 \%$ was of agricultural/agribusiness origin (LEI-DLO, 1991). Livestock production and horticulture are the most important sectors of Dutch agriculture (Table 1). The livestock sector is transforming feed grains, tapioca and other feedstuffs into protein rich animal food products, in particular milk and pigmeat. Substantial quantities of feedstuffs are imported and livestock products are exported. This marketing policy of Belgian and Dutch agriculture has benefitted from the convenient geographic situation of these countries between population centers of Western Europe: Germany, Great Britain and France.

Horticulture is very important nowadays, realizing in 1990, $23 \%$ of Belgian and $30 \%$ of Dutch agricultural output (Table 1). Fresh vegetables are mainly being produced in glasshouses. Horticulture has a long tradition in the western part of the countries, near the sea coast. It has expanded substantially since the fifties because of increasing demand for fresh produce.

The relative importance of the three main production sectors (arable land, livestock and horticulture) is quite similar in both countries. Within Belgium, arable production is dominating in the Southern region, while the Northern region is specializing in livestock and horticulture.

\section{The Food Consumer}

Food consumption in Belgium and the Netherlands amounted to $17.1 \%$ and $18 \%$ of total private consumption in 1990 (LEI-DLO, 1992; NIS, 1991). Total food expenditure is increasing modestly and somewhat less than total consumption, the Dutch index of domestic consumption of food and luxuries for instance increased by $13 \%$ in volume in the period $1980-1990$, while the index of total consumption increased by $16 \%$ in volume during the same period.

While total food consumption has increased to a limited extent, 


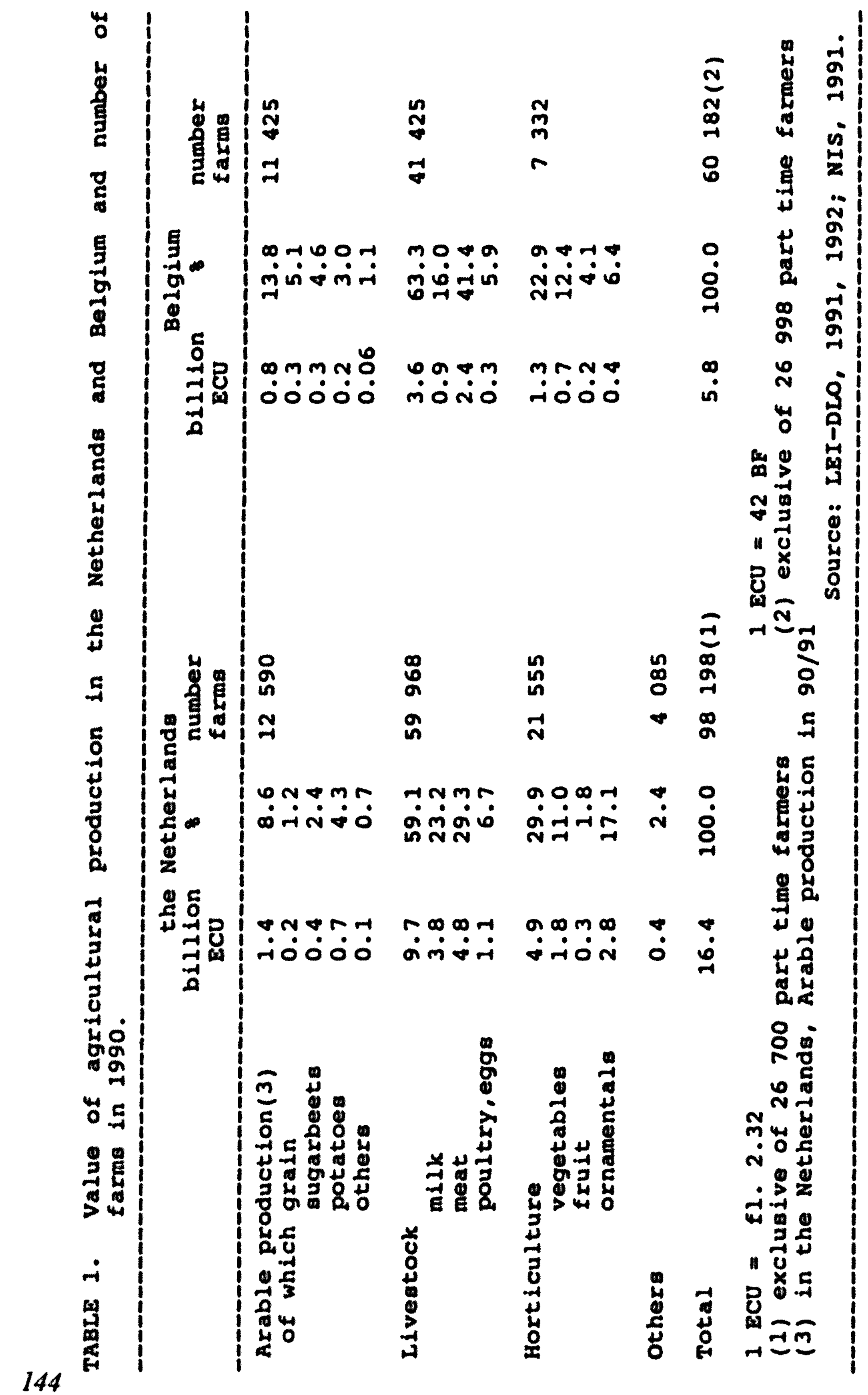


the composition of the food basket has changed substantially. In both countries per capita consumption of animal proteins increased during the past ten years, due to rising consumption of poultry meat, pigmeat and cheese. The growth of per capita consumption of fresh vegetables and poultry meat is in conformity with the generally observed increasing preference for food with low fat content. Per capita pigmeat consumption increased because of relatively low prices, while the increase of per capita cheese consumption may be caused by consumers' desire for tasty food and for variety in food. It is interesting to notice that the decrease of per capita food consumption relates to products which had in 1980 a comparatively high per capita consumption in the respective country: bread, potatoes, butter and beef in Belgium and milk, margarine and sugar in the Netherlands.

Various demographic changes, familiar to Westem societies, influence the development of food marketing: minor growth, or even stagnation of total population, the ageing of the population and decreasing household size. While Dutch population is expected to increase just from 14.9 million to 15.9 million in the period $1990-2000$, Belgian population is forecasted to decrease, from 9.8 million to 9.6 million during the same period. The proportion of people being 60 years and older did increase from $15.6 \%$ to $17.5 \%$ in the Netherlands during the period 1980-1991, and is forecasted to increase from $20 \%$ to $25 \%$ in Belgium over the period 1985-2010. It is expected that one person-households will increase from $23 \%$ in 1980 to $33 \%$ in 2010 in Belgium and from $21.4 \%$ in 1983 to $39 \%$ in 2000 in the Netherlands (AGB, 1992).

Belgian food consumers are more quality conscious than Dutch consumers (Steenkamp, 1992), for instance, Belgians consumed more high quality food like butter, beef/veal and fresh vegetables than Dutchmen in 1990 (Table 2). Nevertheless there is much similarity between Belgian and Dutch consumers in the product attributes which influence their food choice: attributes determining food choice of Belgian food consumers are freshness, taste and ease to prepare (Huygebaert a.0., 1987); taste was considered the most important of thirteen food attributes by Dutch consumers (Steenkamp a.o., 1986). In other research naturalness, healthiness and absence of noxious additives were reported to be the most important 


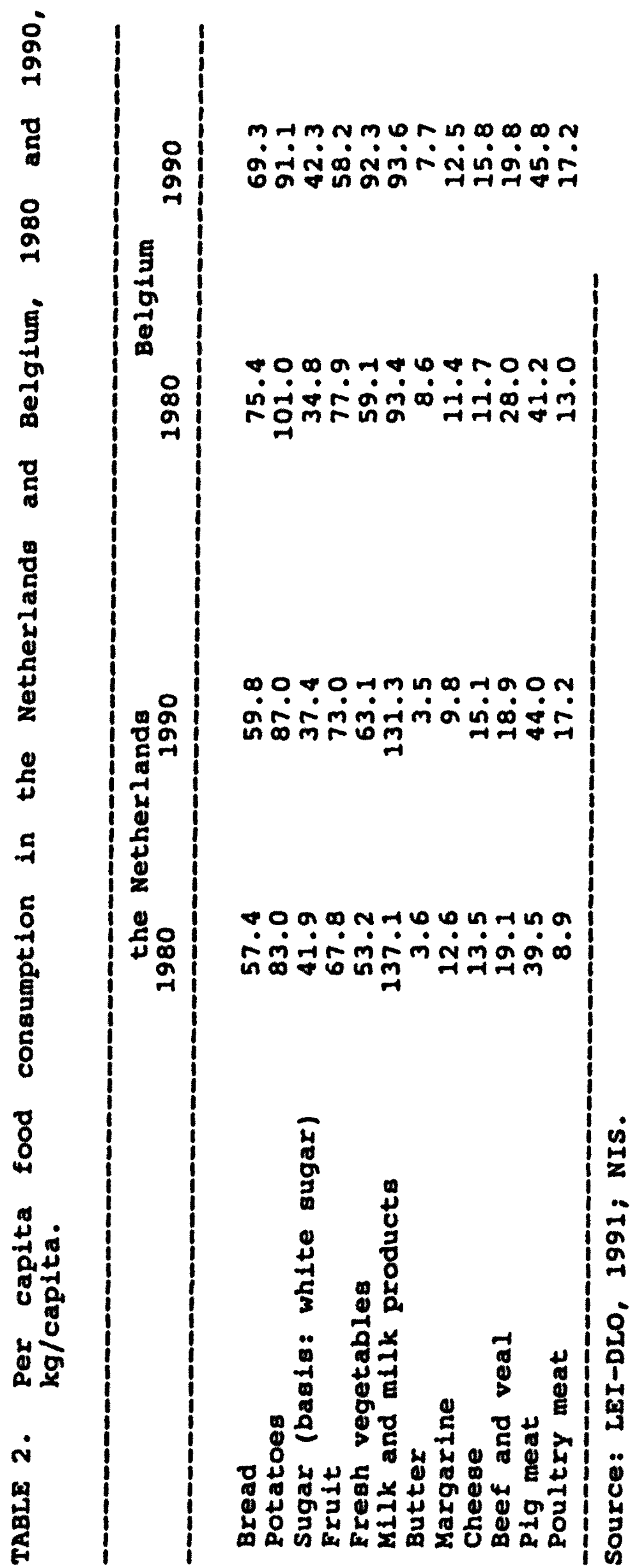


food attributes for Belgian and Dutch food consumers (Steenkamp, 1992). So it is not surprising that Belgian food consumers in a survey of 1986 expected a consumption increase for low fat milk, low fat cheese, whole wheat bread, fresh vegetables and fresh fruit and a decrease for fat meat, sugar, white bread, butter and cream (Huyghebaert a.o., 1987). Health considerations seem to be the dominating criterion for consumers choosing organic food (Oude Ophuis, 1991).

These developments in consumer behavior demonstrate the need for consumer orientation in agricultural marketing, and have brought product development and promotion in the center of agricultural marketing.

\section{CHANGES IN RETAILING}

Like in all Western countries food retailing has shifted from small independents, grocery stores, greengrocers, butchers' shops and bakeries, to large food chains. In Belgium the integrated middle size distribution chains in particular have increased their market share over the period 1980-1990. The distribution or "bolt" law of 1975 regulates the geographical spread of retail outlets. This law aims at optimizing the provision of food products to consumers. As a result the integrated mass distribution could not increase its market share. In the Netherlands no such type of law exists and national food chains increased their share in total food retailing from $21 \%$ in 1970 to $47 \%$ in 1990 (De Jong, 1989). Dutch integrated distribution realized a market share of $64 \%$ in 1990 . Integrated mass distribution increased its market share from $37 \%$ in 1985 to $41 \%$ in 1990 (Table 3).

Developments in food retailing in Belgium and the Netherlands can be characterized by concentration, specialization and internationalization. The market share of the two biggest food retail groups in Belgium has increased from $31 \%$ to $41 \%$ over the period 1982-1989. Specializing on selling fresh food is becoming more important and food retailing is internationalizing both by penetration of foreign retail companies in the Belgian food market, like the British company Marks and Spencer and the German company Aldi, and by foreign subsidiaries of Belgian retail companies, like 


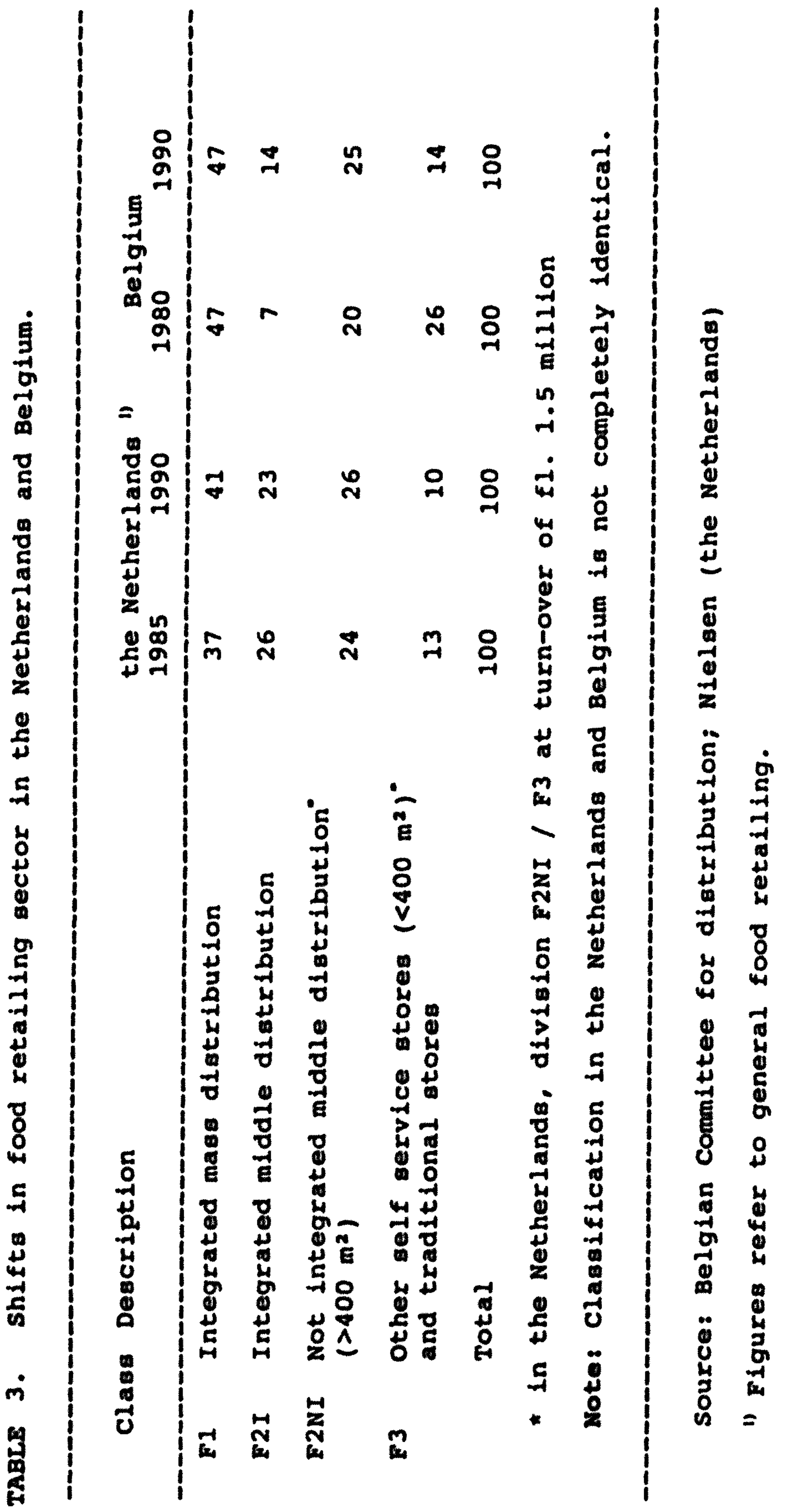


"Food Lion" of the Belgian chain Delhaize in the U.S.A. In the Netherlands the holding company Ahold Ltd, through its food chain "Albert Heijn" and its majority share in a wholesale company which runs a voluntary chain, commands a market share in general food retailing of $37 \%$. German food retail chains, like Aldi and Tengelmann, have penetrated in Dutch food retailing. Small food retailers try to survive by specializing, by joining voluntary chains or by participating in franchise operations. However, their number is decreasing. The following developments have a great impact on market behavior of food chains in Belgium and the Netherlands:

- retail chains develop strong images and focus on well defined target groups, by specific assortment, product quality, services and pricing,

- private labeling will become even more important yet,

- efficiency improvement-in particular logistical efficiency-is important; logistical planning models, scanning operations and Electronic Data Interchange more and more contribute to efficiency improvement,

- cooperation and coordination between retail chains will increase, in particular by franchising and by alliances.

As a result, marketers of food and agricultural products have to deal with food chains which have substantial purchasing power. They have to build up a competitive edge by appropriate marketing policies. Such policies not only require specific product quality and discounts, but also cooperation on advertising and logistical service. They have stimulated marketing management in agricultural marketing and have changed market structure of agriculture and food industry.

\section{GOVERNMENT POLICIES}

Government is playing an important role in agricultural markets. Classical reasons for government market interference are food security, farmers' welfare, economic importance of agriculture, respectively health and environmental considerations. Except during world war periods, food security has not been an important motive 
in Belgium and the Netherlands. Export orientation and limited importance of arable farming resulted in a non-protectionist food policy in these countries.

Belgian and Dutch governmental agricultural policy has to operate within the rules of the CAP. In addition governments have subsidized some types of investments in order to improve farming efficiency. Government support to farmers has been focused in particular on the improvement of farming quality by research, extension and education.

A number of factors, like dissatisfaction with CAP, environmental problems, the smaller economic importance of agriculture, and budget problems diminish willingness of Belgian and Dutch politicians to support agriculture. So, there is a tendency nowadays to privatize a number of public services to farmers, e.g., agricultural extension services.

Like in other countries, government is involved in agriculture by protecting consumers and environment: food and drugs laws, antitrust legislation, legislation on the use of insecticides, pesticides and drugs and, increasingly, environmental legislation which put side conditions on agricultural production and marketing. In the future agriculture in Belgium and the Netherlands will have to rely more on marketing potential and less on government support.

\section{Changes in Competition}

Competition in agricultural and food markets has increased because of the EC. In evaluating the competitive strength of Belgian and Dutch agriculture, Porter's criteria "factor conditions, demand conditions, related and supporting industries, respectively firm strategy, structure and rivalry" (Porter, 1990) seem relevant. With respect to factor conditions, it can be argued that the created factors, i.e., skilled farmers and good allocation of farm land, are more important in giving agriculture a competitive edge than natural advantages such as to climate, soil and water. As far as demand conditions are concerned, it looks as if Belgian consumers are more quality conscious, and Dutch consumers more price conscious. In this respect consumers' attitude, at least in the Netherlands, does not seem instrumental in strengthening the competitive position of agriculture. Belgian and Dutch agriculture seem to have a competi- 
tive advantage on the criterion 'Related and supporting industries.' Agriculture, in particular horticulture, in Belgium and the Netherlands is concentrated in specific areas, where there is a good infrastructure of supporting industries and trading companies, which deliver specialized products and services to farmers. Various producer networks exchange experiences and opinions on a regular basis. Firm strategy, structure and rivalry in domestic market, the fourth criterion of Porter, are in particular relevant to agribusiness and food companies, because of the open EC market. Because of strong export orientation, Belgian and Dutch agribusiness are more used to operating in competitive markets than some of their colleagues in the EC. Porter mentions two additional factors being of importance for competitiveness, namely government and chance. Governments have paid ample attention to the improvement of farmers' skills and of infrastructure, which has strengthened competitiveness. Competitive position of Belgian food industry could be strengthened by improving technology and workers' skill, respectively by increasing company size. In the Netherlands also a large number of companies are too small to compete effectively in international markets (Table 4).

Belgian and Dutch agriculture and food industry have built up a strong export position. Belgium has become a net-exporter of food products since 1983, while the Netherlands has been a net exporter of food products for a long time. Belgian and Dutch food and agricultural products are mainly exported to EC countries, in particular Germany, France and the United Kingdom. While France is the most important export market for Belgian food products, Germany is the dominating export market for Dutch agricultural and food products. Dutch agriculture/horticulture and food industry also export substantial quantities of products, like flower bulbs, to third countries out of the EC. Product quality and services have become very important as a competitive weapon.

A competitive disadvantage of Dutch agriculture, and to some extent of Belgian agriculture also, are the costs of environmental problems, caused by the manure from intensive methods of animal husbandry and by the intensive use of fertilizers and pesticides. 


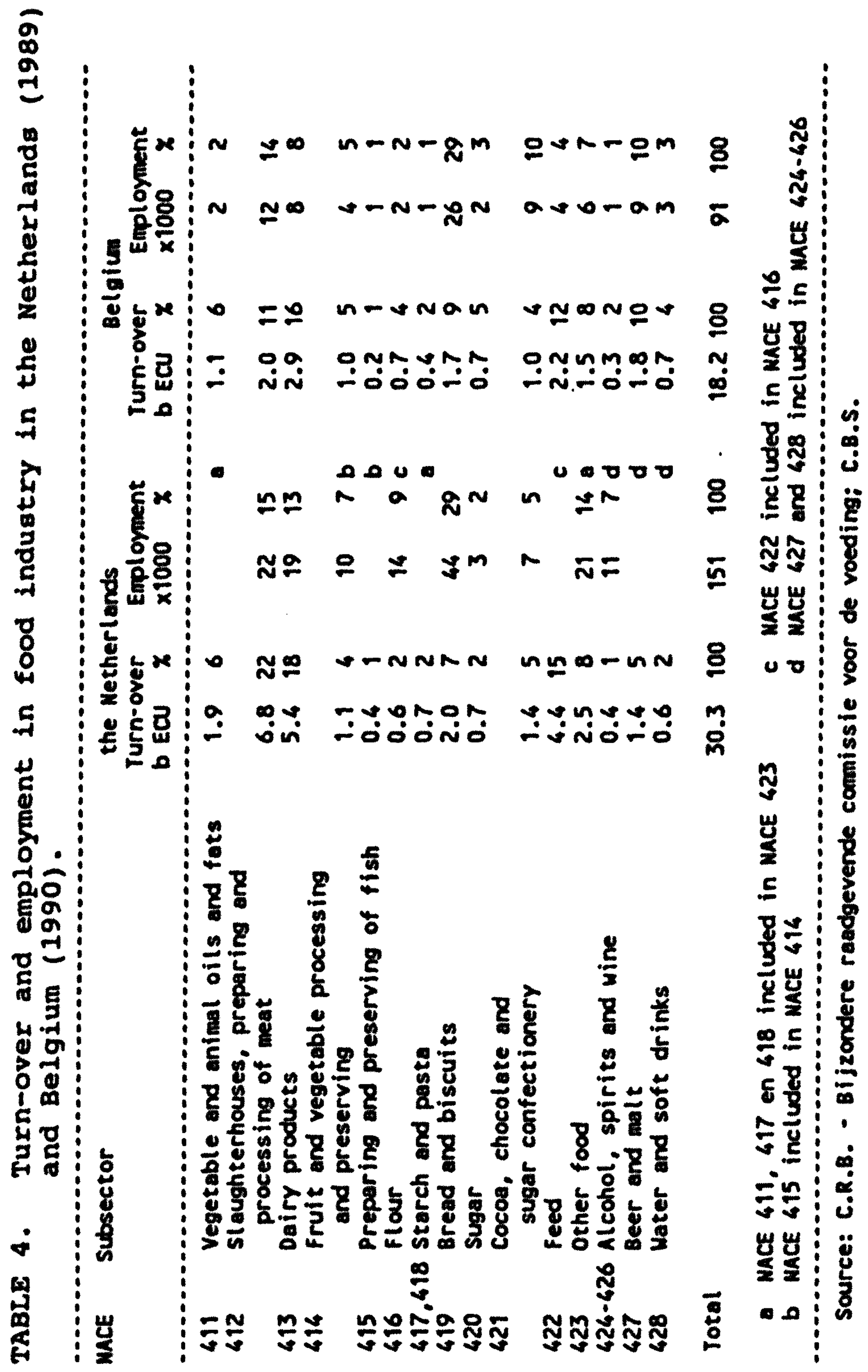




\section{MARKETING CHANNELS AND MARKETING INSTITUTIONS}

The structure of agricultural marketing channels is changing. The functions to be performed in the channel, the institutions of the marketing channel and the relationships between these institutions are changing.

Farms, being mainly family farms, have specialized, for instance into fruit growers, growers of fresh vegetables, poultry farmers, pig farmers and dairy farmers. Typically, agricultural products are marketed by wholesale companies and/or processing industries, both private and co-operative. Direct selling from farm to consumers is of minor importance.

Agribusiness and food business increasingly contribute to the marketing of agricultural products by processing, packing and offering services to the final customer. Food industry realized $3.2 \%$ of the gross national product in the Netherlands and 3.2\% in Belgium in 1990.

There are specific differences in the importance of various sectors of the food industry between both countries: in Belgium, breweries are more significant since by tradition beer consumption is of more importance; in the Netherlands processing of cocoa-beans is more important because of the historical relationships with tropical production areas. In both countries there are a great many small food companies as yet. In Belgium for instance $82 \%$ of the food companies, being responsible for $19 \%$ of the employment of the sector, do have less than 10 employees. Concentration and internationalization are central tendencies in the food industry. In Belgian food industry a few large national companies are market leaders, like Vandermoortele for oils, Van den Broecke for processed potatoes, Leonidas for pralines, Spadel for mineral water and Interbrew for beer. In other fields foreign companies are market leaders. In the Netherlands, multinational food companies are leading in various food markets, like Unilever in margarine, D.E./Sarah Lee in the coffee market, while three national co-operatives dominate the dairy market. Increasing competition of multinationals in the large European food market, and concentration in food retailing are main challenges to the food industry. The aim of creating added value by processing agricultural products stimulates attention for product quality, amongst others by integrated quality control and branding. 
Logistics is becoming more important in order to increase customer service and to improve efficiency.

Belgian and Dutch wholesalers of agricultural and food products have lost market share, like for instance in marketing pigs, cheese and groceries, to forward and backward integrating industries and retail chains. They have maintained a strong position in marketing of perishables like flowers, fresh vegetables and potatoes.

Co-operatives are very important in Dutch agriculture and are of substantial importance in Belgian agriculture (Table 5). They are in particular important for perishable products which cannot be stored at the farm, like milk and fresh horticultural products, and in agricultural sectors having an important export share.

Many co-operatives started out as local or regional businesses at the end of the nineteenth century. They became more market oriented in order to suit the needs of the market. Market orientation stimulated a development towards large co-operatives; in the Netherlands three co-operative companies account for more than $80 \%$ of Dutch milk supply, two co-operative auctions dominate the Dutch flower market and one co-operative the potato processing for industrial purposes. By specific organizational structures, like a limited company, whose shares are owned by the co-operative union, cooperatives try to improve effectiveness of decision making and of marketing policies.

Contract farming is important for broilers and for vegetables for canning purposes. In Belgium contract farming has a market share of $95 \%$ for veal, $90 \%$ for broilers, $70 \%$ for eggs and $60 \%$ for pig meat-feed companies and slaughterhouses being the main contractors-flax is almost exclusively produced under contract and potatoes for about $50 \%$.

Technical markets have become less important in agricultural marketing. They are still important for livestock, and in particular for fresh horticultural products. In the Netherlands there are two futures markets, respectively for potatoes and live pigs.

Being introduced in 1887 , auctions have gradually become the dominating marketing institution in Dutch horticulture (Meulenberg, 1989). They are very important in Belgian horticulture too. Dutch auctions have expanded activities from price discovery and product assembly into other marketing activities, such as minimum 


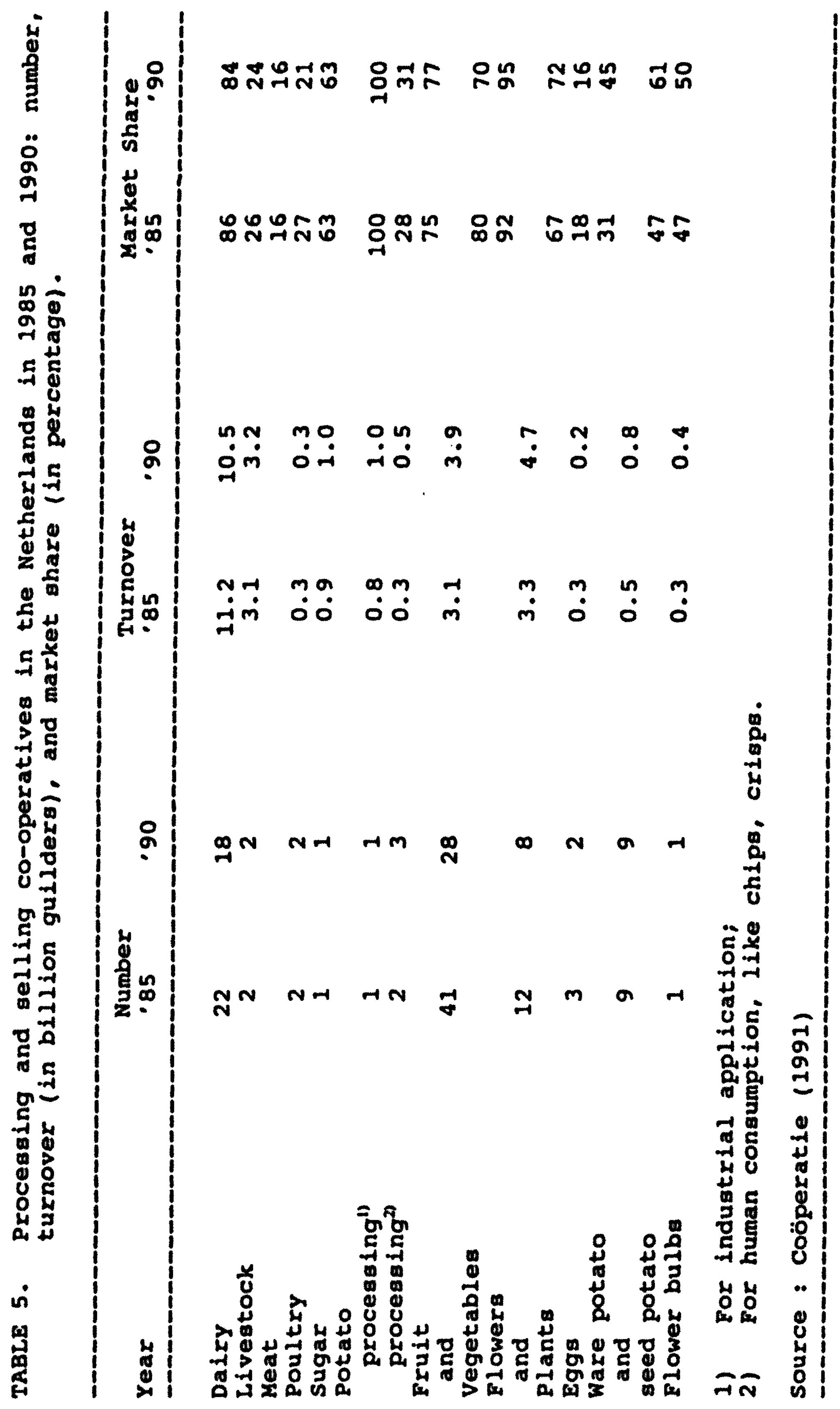


pricing schemes, promotion, logistics, and product policy. Dutch auctions cooperate in master organizations which coordinate activities, like national minimum price schemes and promotional activities. Some retail chains are critical of the auction system, since daily purchasing through auctions does not fit to retail sales planning. Co-operative auctions have developed additional selling operations, such as brokerage operations in pot plants and auctioneering for delivery at a future time period.

In Dutch agriculture commodity boards exist in many sectors, like milk and dairy products, meat and meat products, and ornamentals. They do not engage in buying and selling but are engaged in market research, promotion and technical research for the generic product. The total promotional budget of Dutch agricultural commodity boards amounted to 144.2 million guilders in 1989. Commodity boards were set up in the fifties, when agricultural markets typically existed of a great many small farms and processing companies. At present various agribusiness firms, including co-operatives, have become national or even international companies which run individual marketing programs. As a result agribusiness firms are less in a need for generic marketing programs like those set up by commodity boards.

\section{MARKETING CONDUCT OF BELGIAN AND DUTCH AGRICULTURE}

Marketing conduct of Belgian and Dutch agriculture and agribusiness is evolving from performing marketing functions (exchange-, physical- and facilitating functions) to marketing management (organizing the marketing mix in view of customers wants and needs). Clearly there is no strict borderline between these two approaches. In fact, marketing management is integrating the planning of marketing functions in a broader framework. Marketing conduct of Belgian and Dutch agriculture will now be discussed within the framework of the marketing instruments.

Product. Product policy has become a core element of agricultural marketing programs. Product quality and product assortment are very important marketing topics: Dutch pig sector is aiming at leaner meat, the percentage of lean meat increased from $53.2 \%$ in 
1990 to $53.8 \%$ in 1991; dairy industries processed more milk into more profitable products like desserts and cheese $(45.4 \%$ of Dutch milk supply was processed into cheese in 1989 and $48.6 \%$ in 1991); during the period 1989-1991. Dutch production of red peppers, mushrooms and cucumbers has increased more than that of other vegetables (LEI-DLO, 1991, 1992).

Research and development, product innovation and branding have become extremely important in agricultural marketing. Integrated quality control, certification of products and production processes are introduced, amongst others for fresh meat, in order to guarantee product quality. Environmentally friendly food production is expanding, like for instance organic food production and animal friendly production methods. The market for organic food in the strict sense, like bio-dynamic and ecofood is limited yet.

Price. Traditionally, agricultural prices were determined by the interaction of supply and demand at technical markets. In some instances, like fresh horticultural products, this still happens to be the case. In other markets price formation by contract is important, such as in the case of fruit and vegetables for canning purposes and markets for broilers.

In Belgium and the Netherlands marketing margins between retailer and producer prices are increasing because more value is added to the agricultural product. In Belgium producer share in consumer prices decreased from $70 \%$ to $58 \%$ for beef and from $54 \%$ to $42 \%$ for pigmeat during the period 1981-1990 (Huyghe, 1991). In the Netherlands the share of agriculture, in total expenditure for food and luxuries, decreased from $41 \%$ in 1961 to $28 \%$ in 1988 , the share of distribution increased from $35 \%$ to $45 \%$ and the share of processing from $24 \%$ to $27 \%$ (LEI-DLO, 1992).

Promotion. In agricultural and food marketing promotion is an extremely important instrument for creating consumer awareness and product image. It is increasing in conjunction with product differentiation and competition. Co-operative promotion by food producers and food retail chains is important in marketing agricultural and food products too.

In spite of the growing importance of company brand promotion, collective promotion for agricultural and food products is of importance yet. In Belgium three institutions are engaged in collective 
promotion for agricultural and food products. The first is ONDAH, established under the direction of the Ministry of Agriculture, which aims at controlling product quality and at the promotion of agricultural products. Since 1984 the private sector is more involved in ONDAH by fund raising and decision making. Since 1990 two marketing offices, in Paris and Bonn, support Belgian exporters of food and agricultural products. The second institution is BDBH (Belgian Office for External Trade), a public institution established in 1948, which is offering trade services for semi-processed and processed export products. The third is Vitabel, the export department of the Federation of the Agri-Food Business, LVN, which supports producers and wholesalers of food products, in particular with respect to foreign trade fairs. The tendency towards regionalization of Belgian collective promotion leads to scattered promotions and promotional impact.

In the Netherlands commodity boards and co-operative master organizations, for instance in fruit and vegetables, are engaged in collective promotion. Collective promotion financed by commodity boards amounted to 144 million guilders in 1989. Determining the appropriate balance between brand promotion by individual companies and generic promotion is a hot issue in Dutch agricultural marketing.

Distribution. Food producers compete for shelf space of retail companies. Purchasing loyalty of retail companies has become very important for Belgian and Dutch agricultural and food producers. Building a direct relationship with food retail chains is instrumental in this respect. As a result distribution policies in agricultural marketing are increasingly concerned with strategic decision making about marketing channels. In various sectors of Belgian and Dutch agriculture vertical marketing systems have emerged: some dairy co-operatives have integrated cheese wholesale companies; some compound feed companies have integrated meat packing companies.

Logistical operations throughout the marketing channel of fresh products such as the marketing channels for fresh meat or pot plants are planned more thoroughly. New information technology, like E.D.I., is helpful in this context.

Transport is particularly important for voluminous perishable products like fresh horticultural products, fresh meat and dairy products. Food producers and middlemen often purchase transport ser- 
vices from specialized transport companies. In the Netherlands $49 \%$ of wholesalers in agricultural products and 39\% of wholesalers in food products contract out transport in domestic markets; these figures are respectively $77 \%$ and $63 \%$ for international transport (Nederlands Verbond van de Groothandel, 1991).

\section{PERFORMANCE OF AGRICULTURAL MARKETING IN THE NETHERLANDS}

We do not have data at our disposal to assess marketing performance at the sector level, or of some specific marketing companies by methods developed for that purpose (Bonoma and Clark, 1988). So our discussion of marketing performance must remain tentative and of a qualitative type.

Some indication of marketing performance/market orientation might be provided by farmers' income, which, however, not only depends on marketing operations but also on production efficiency of farmers and on farm support by CAP. It appears that family income per family worker in agriculture is higher in the Netherlands than in any other country of the EC: $25,200 \mathrm{ECU}$ in 1988/89 and $31,700 \mathrm{ECU}$ in $1989 / 90$ as compared to respectively $8,200 \mathrm{ECU}$ and 9,400 ECU in the EC on average and respectively 22,300 ECU and 27,100 ECU in Belgium, being second highest (LEI-DLO, 1991, 1992). These figures suggest a fair marketing performance of Belgian and Dutch agriculture, at least relatively speaking.

High prices might suggest monopolies or inefficiencies in marketing operations. However, market prices can be high because of more built in services or higher product quality, or because of CAP measures. Farmers' prices in Belgium and Netherlands in general are low as compared to prices in other EC countries (Eurostat). Prices are in particular low for pigs, poultry and eggs.

Another indicator of marketing performance might be the dynamics of market supply, both in terms of quantity and quality. In fact Belgian and Dutch agricultural markets have been very dynamic during the past ten years. Sales and exports have changed substantially, in particular in horticulture, poultry business and dairy industry (LEI-DLO, 1991).

Quality control has received much attention. In horticulture prod- 
uct innovation has been substantial. In fruit growing new apple-varieties have been introduced. The assortment of vegetables in glasshouses has been extended substantially. The number of new flower varieties has been overwhelming. In arable farming, being a troubled sector today, product innovation to a large extent has been experimental without great success up till now. Production and marketing of organic food, or of products produced in an animal friendly way, is increasing.

\section{CONCLUSION}

Marketing agricultural products in Belgium and the Netherlands is increasingly an operation in an environment characterized by a saturated demand, by a changing CAP, an environmentally conscious society and a more critical and better informed consumer. These challenges require marketing policies aiming at more added value and environmentally friendly production methods.

As a result marketing management has become more familiar in agricultural marketing and has stimulated larger firm size in agribusiness. As a result mergers are under way leading to internationally oriented agribusiness companies which have entrenched themselves firmly in the food chain.

\section{LITERATURE}

AGB, (1992). Jaargids, Kerncijfers voor markt- en beleidsonderzoek, Dongen.

Bain, J. S. (1959). Industrial Organization, New York, John Wiley and Sons.

Baln, J. S. (1956). Barriers to New Competition, Cambridge, Harvard University Press.

Bertrand, J. M. (1989). Les filières agro-alimentaires. Etude bibliograpbique. Documents de l'I.E.A., $\mathrm{n}^{\circ} 25$, février 1989, 48 p.

Bertrand, J. M. (1989). Les filières agro-alimentalres. Etude bibliograpbique. Documents de l'I.E.A., $n^{\circ} 25$, février 1989, 48 p.

Bonoma, T. V. and B. H. Clark (1988). Marketing Performance Assessment, Harvard Business School Press, Boston, Massachusetts.

Cassady, R., 1967. Auctions and Auctioneering, University of California Press, Berkeley.

Centrale Raad voor het Bedrijfsleven: Bijzondere Raadgevende Commissie voor de Voeding (1991). Verslag over de economische ontwikkeling in de voeding- 
smiddelensector in 1990 en tijdens het eerste halfjaar van 1991. Brussel, 5 juli 1991, 48 p.

Centrale Raad voor het Bedrijfsleven: Bijzondere Raadgevende Commissie voor de Voeding (1991). De voeding en de dranken in het particulier verbruik. Brussel, 4 November 1991, 23 p.

Commission of the European Communities: Directorate-general for Agriculture (1990). The agri-food business in the Community. CAP working notes, 1990.

De Craene, A. \& Viaene, J. (1990). Promotie van de export van voedingsmiddelen in het perspektief van 1992. Seminarie voor AgroMarketing, RUG, in opdracht van het Staatssecretariaat voor Europa 1992, oktober 1990, 98 p.

Gallet, G. \& Viaene, J. (1989). De impact van 1992 op de voedingsindustrie. Seminarie voor Agro-Marketing, RUG, in opdracht van het Staatssecretariaat voor Europa 1992, mei 1989, 172 p.

Huyghe, F. (1991). De groot- en detailhandelsmarges voor rund-en varkensvlees. CLEO-schriften, nr. 59, juni 1991, 57 p.

Huyghebaert, A.; Viaene, J. \& De Vrieze, M. (1987). Perspectieven van de voedingsconsumptie in Belgie. Diensten voor Programmatie van het Wetenschapsbeleid, Brussel, 1987, 93 p.

Jong, J. G. A. M. de (1989). De functionele plaats van de distributie in beweging: 1970-1990, in: Bunt, J., Dreesmann, A. C. R. and C. Goud, 1989, Dynamiek in de Distributie, Kluwer, Deventer, pp. 3-19.

LEI-DLO (1991). Landbouweconomisch Bericht 1991, Den Haag.

LEI-DLO (1992). Landbouweconomisch Bericht 1992, Den Haag.

Ministerie van Landbouw (1991). Evolutie van de land- en tuinbouweconomie (1990-1991), 29ste verslag voorgelegd door de regering. L.E.I., Brussel, November $1991,185 \mathrm{p}$.

Oude Ophuis (1992). De Europese markt voor alternatief geproduceerde voedingsmiddelen. In: Steenkamp, J.E.B.M. (ed.). De Europese consument van voedingsmiddelen in de jaren negentig, Van Gorcum, Assen/Maastricht, pp. 31-47.

Porter, M. (1990). The Competitive Advantage of Nations, MacMillan, 1990.

Rabobank (1991). Cijfers en Trends, Rabobank, Nederland.

Smith, J. (1990). The Community agri-food industry in the single market. Club de Bruxelles, 1990.

Steenkamp, J.E.B.M. (1992). Cross-nationale analyse van het kwaliteitsbewustzijn van consumenten met betrekking tot voedingsmiddelen. In: Steenkamp, J.E.B.M. (ed.). De Europese consument van voedingsmiddelen in de jaren negentig, Van Gorcum, Assen/Maastricht, pp. 127-136.

Steenkamp, J.E.B.M.; Wierenga, B. \& Meulenberg, M.T.G. (1986). Kwaliteitsperceptie van voedingsmiddelen. Swoka, Verkennende studie, 40-1, 402-2, Den Haag.

Van Den Bulcke, D. et al. (1988). De Belgische voedingsnijverheid: economische tendensen en technologische perspectieven. Diensten voor Programmatie van het Wetenschapsbeleid, Brussel, 1988, 72 p.

Viaene, J. (1991). Aspects socio-economiques des mutations du complexe agroindustriel. Annales de Gembloux: - 1997. 97: p. 95-113. 